Dikirim: 22 Juni 2016 Diterbitkan: 1 November 2016

\section{Pola sebaran tingkat infeksi bersama serotipe virus dengue di wilayah kajian RT-PCR Balai Besar Teknik Kesehatan Lingkungan dan Pengendalian Penyakit Yogyakarta: analisis data 2013-2015}

Pattern of concurrent infection of dengue virus serotype in the regional study areas of Yogyakarta Center for Environmental Health and Diseases Control: an analysis of 2013-2015 data

Fitria Wakano ${ }^{1}$, Lutfan Lazuardi ${ }^{2}$, Eggi Arguni ${ }^{3}$, Hari Kusnanto ${ }^{1}$

\begin{abstract}
Purpose: This study aimed to determine the pattern in the spread of infection rates with dengue viral serotypes. Methods: The study was a descriptive research with spatial mapping methods. Data of 132 respondents were collected based on RT-PCR in 2013-2015. The complete address of the village-level patient from the dengue arbovirosis surveillance data of the Center for Environmental Health and Diseases Control Yogyakarta were used to determine the coordinate points with utilization of RBI and Google Earth maps in searching addresses for distribution of case coordinate points. Results: There were similarities with the most complex quadruple joint infection rates of DEN in Semarang and Yogyakarta, while Kebumen obtained double DEN level. Three patterns of infection with DEN-1 and DEN-3 have p-value < 0.05 in Semarang in 2014, Sragen in 2015 and Semarang 2013 and 2 patterns in Gunung Kidul 2014 and Kulon Progo 2015. The patterns of infection with DEN-1, DEN-2 and DEN-3 in 2015 were covering Sragen and Semarang in 2013. Conclusion: The most complex areas of infection were Semarang and Yogyakarta. The pattern of most likely cluster infection with DEN-1 and DEN-3 and DEN-1, DEN-2 and DEN-3 allegedly was a result of two infected patients, different serotypes of different mosquitoes or infection of more than one serotype of Ae. aegypti or Ae. albopictus as the main vector.
\end{abstract}

Keywords: region; level of joint infection; serotype; dengue virus

\footnotetext{
${ }^{1}$ Departemen Biostatistik, Epidemiologi, dan Kesehatan Populasi, Fakultas Kedokteran, Universitas Gadjah Mada (Email: fit.wakano@gmail.com)

${ }^{2}$ Departemen Kebijakan dan Manajemen Kesehatan, Fakultas Kedokteran, Universitas Gadjah Mada

${ }^{3}$ Departemen Ilmu Kesehatan Anak, Fakultas Kedokteran, Universitas Gadjah Mada
} 


\section{PENDAHULUAN}

Indonesia memiliki jumlah infeksi virus dengue terbesar di antara negara-negara Asia Tenggara dengan perkiraan 80.065 kasus pada 2010 (1). Kasus pertama di Indonesia dengan pemeriksaan serologis dibuktikan pada tahun 1969 di Surabaya. Angka kematian karena infeksi virus dengue menurun secara drastis dari 41,3\% di tahun 1968, menjadi kurang dari 3\% di tahun 1991, namun infeksi dengue masih merupakan kegawatan yang sulit diatasi (1).

Berdasarkan sifat anti gen virus dengue memiliki empat serotipe, meliputi: DEN-1, DEN-2, DEN-3 dan DEN-4. Seluruh serotipe virus tersebut terdapat di Indonesia, DEN-3 merupakan serotipe yang paling sering ditemukan diikuti DEN-2, DEN-1 dan DEN-4 (2). Penelitian terdahulu di Surabaya tahun 2005-2009 menunjukkan virus infeksi dengue didominasi oleh DEN-2 dan di tahun 2012 didominasi oleh DEN-1 serta ditemukan infeksi ganda oleh dua serotipe yang berbeda (1). Fenomena kejadian infeksi bersama lebih dari satu serotipe virus dengue dengan diagnosis klinis grade IV diketahui di Jawa Timur sejak 2004 melalui pemeriksaan PCR (2). Perubahan dominasi serotipe serta keberadaan infeksi ganda setiap tahun memegang peranan penting dari penyebaran infeksi dengue (3).

Kajian RT-PCR (reverse transcriptase polymerase chain reaction) surveilans arbovirosis dengue yang dilakukan pada semua golongan umur oleh Balai Besar Teknik Kesehatan dan Pengendalian Penyakit (BBTKLPP) Yogyakarta tahun 2013 sampai 2015 di 5 Kabupaten/Kota DIY dan 4 di Jawa Tengah, menemukan dari total 275 isolate sampel penderita, sebanyak 143 berhasil diidentifikasi keempat jenis serotipe dan infeksi bersama oleh serotipe virus dengue, dengan tingkat infeksi bersama: single DEN$34 \%$, double DEN- 52\%, triple DEN-23\% dan quadruple DEN-2\%.

Ciri epidemiologis penyebaran penyakit virus dengue sering ditandai dengan hiperendemisitas atau kemunculan beragam serotipe dengue secara bersamaan. Suatu penelitian di Jakarta menemukan infeksi serotipe DEN-4 dengan tipe tunggal, ganda dan triple (4). Rafiq et al., di Pakistan menemukan bahwa kejadian luar biasa infeksi dengue oleh 2 tipe serotipe (double DEN) ditemukan di 1994, 2005, 2006, 2007 dan 2011, dengan setiap tahunnya terdapat kematian. Jumlah kasus dan kematian yang tertinggi terjadi pada tahun 2011 yaitu \pm 20.000 kasus dan $\geq 300$ diantaranya meninggal dunia. Infeksi oleh 3 serotipe yang berbeda (triple DEN) terjadi di 1995 dengan 75 kasus dan sebanyak 57 meninggal dunia dan pada tahun 2008 didapatkan 1800 positif kasus dengan triple DEN (DEN-2, 3 dan 4) yang berdampak pada frekuensi tinggi demam berdarah dengue (5).

Analisis spasial sebaran serotipe pada infeksi dengue secara epidemiologi sangat penting dilakukan. Dengan analisis spasial, data spasial dan data atribut diolah menjadi informasi spasial, yang dapat digunakan sebagai alat bantu dalam perumusan kebijakan, pengambilan keputusan, dan/atau pelaksanaan kegiatan yang berhubungan dengan ruang kebumian. Dalam epidemiologi, analisis spasial sangat bermanfaat, terutama untuk mengevaluasi terjadinya perbedaan kejadian menurut area geografi dan mengidentifikasi clustering penyakit (6).

Pemetaan pola sebaran infeksi dengue dan serotipe tunggal pada infeksi dengue telah banyak dilakukan, akan tetapi sepengetahuan peneliti penelitian tentang pola sebaran tingkat infeksi bersama serotipe dengue belum pernah dilakukan, terutama di wilayah kajian BBTKLPP Yogyakarta. Penelitian ini dilaksanakan dengan tujuan untuk mengetahui pola sebaran tingkat infeksi bersama serotipe virus dengue di wilayah kajian RT-PCR BBTKLPP Yogyakarta tahun 2013-2015.

\section{METODE}

Penelitian ini menggunakan data sekunder dengan jenis penelitian observasional melalui pendekatan studi deskriptif dan analitik cross-sectional. Penelitian ini bertujuan untuk melihat pola sebaran tingkat infeksi bersama serotipe pada infeksi virus dengue yang dilakukan dengan menggunakan analisis spasial (google Maps/Earth). Alamat lengkap penderita (sampai level desa) pada kajian RT-PCR yang diperoleh dari data surveilans arbovirosis dengue BBTKLPP Yogyakarta, digunakan untuk menggambarkan titik koordinat dengan pemanfatan peta RBI sebagai penentuan batas geografis dan google Earth untuk mencari alamat/desa serta pembuatan sebaran titik koordinat dari setiap responden, mengingat wilayah kajian RT-PCR surveilans arbovirosis dengue oleh BBTKLPP Yogyakarta cukup luas mencakup DI Yogyakarta dan Jawa Tengah.

\section{HASIL}

Gambaran Umum. BBTKLPP Yogyakarta adalah Unit Pelaksana Teknis (UPT) yang berada langsung di bawah Kementerian Kesehatan dan bertanggung jawab kepada Direktorat Jenderal Pengendalian Penyakit dan Penyehatan Lingkungan, bekerja pada dua provinsi 
yaitu Jawa Tengah dan DIY dengan tugas pokok dan fungsi: pelaksanaan surveilans epidemiologi, kajian dan penapisan teknologi, laboratorium rujukan, kendali mutu, kalibrasi, pendidikan dan pelatihan, pengembangan model dan tepat guna, kewaspadaan dini dan penanggulangan kejadian luar biasa (KLB) di bidang penyakit dan kesehatan lingkungan serta kesehatan matra.

Tahun 2013-2015 BBTKLPP Yogyakarta telah melakukan kajian RT-PCR surveilans arbovirosis dengue di beberapa kabupaten/kota di Jawa Tengah dan DIY secara keseluruhan, seperti yang terlihat pada Gambar 1.

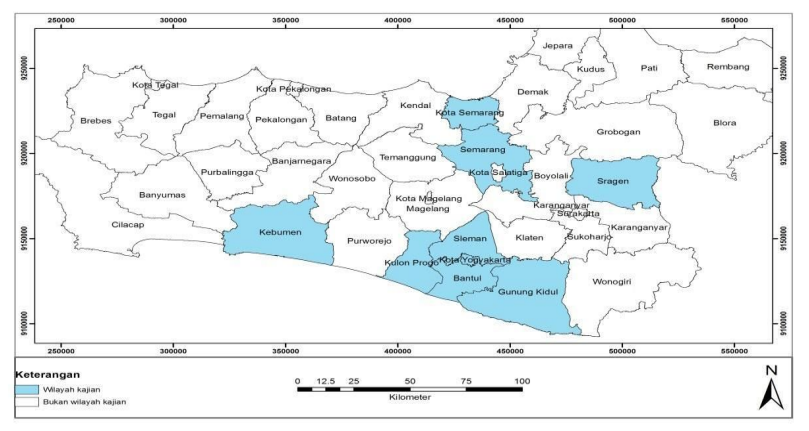

Gambar 1. Wilayah kajian RT-PCR BBTKLPP Yogyakarta tahun 2013-2015

Distribusi tingkat infeksi bersama serotipe virus dengue. Analisis spasial tingkat infeksi bersama dilakukan dengan menggunakan Argis triyal 10.4. Gambar 2 menunjukkan distribusi tingkat infeksi bersama yang paling kompleks quadruple DEN terdapat pada Kota Semarang dan Kota Yogyakarta. Secara umum terdapat double DEN pada Kabupaten Kebumen serta single dan double DEN di Kulon Progo. Pada Kabupaten Semarang, Sragen, Gunung Kidul, Sleman dan Bantul didapatkan infeksi single, double dan triple DEN.

\section{Pola sebaran tingkat infeksi bersama serotipe virus}

dengue. Analisis dengan menggunakan Satscan versi 9.4.2. Metode retrospektif dan pemodelan space time permutation dengan 999 pengulangan dapat mengidentifikasi ada atau tidaknya klaster yang paling mungkin dari setiap tingkat infeksi bersama dengan tipe serotipe yang sejenis.

Tabel 1 menunjukkan hasil analisis pemodelan pada double infeksi DEN-1 dan DEN-2, DEN-1 dan DEN-3 serta DEN-2 dan DEN-3. Terdapat 5 klaster pada infeksi bersama DEN-1 dan DEN-3 yang bermakna, 3 most likely cluster dan 2 klaster sekunder. Most likely cluster meliputi: klaster 1 di wilayah kabupaten Semarang (radius 15258,36, waktu infeksi tanggal 25 Maret sampai 16 April 2014, jumlah kasus 10, nilai expected 2,70 dan $p$ value 0,005), klaster 2 di kabupaten Sragen (radius 11381.42, waktu infeksi mulai tanggal 14 Juni - 22 Juli 2015, jumlah kasus 6, nilai expected 0,97 dan $p$ value 0,011 ) dan klaster 3 di wilayah kota Semarang (radius 10893,89 m, waktu infeksi mulai tanggal 21 - 25 Juni 2013, jumlah kasus 5, nilai expected 0,68 dan $p$ value 0,024 ). Dua klaster sekunder pada kabupaten Gunung Kidul (radius 47723,08 m, mulai 21 April - 18 Juli 2014, jumlah kasus 6, nilai expected 1,14 dan $p$ value 0,052) dan kabupaten Kulon Progo (radius 14858,54 m, mulai 6 - 20 Maret 2015, jumlah kasus 4, nilai expected 0,65 dan $p$ value 0,066 ).

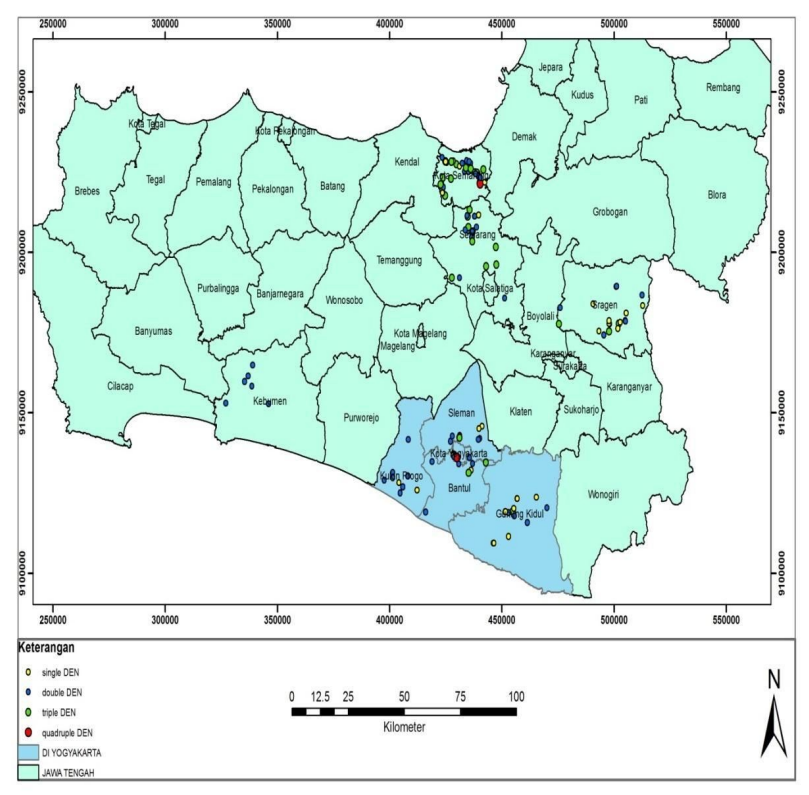

Gambar 2. Distribusi tingkat infeksi bersama serotipe virus dengue di wilayah kajian RT-PCR BBTKLPP Yogyakarta tahun 2013-2015

Tabel 2 menunjukkan hasil analisis pemodelan dari infeksi bersama tiga serotipe DEN-1, 2 dan DEN-3. Terdapat 1 most likely cluster yang berpusat di kabupaten Sragen sampai kabupaten Semarang (radius 50332,35 m, dimulai dari 1 - 23 April 2015, jumlah kasus 9 orang, nilai expected 2,70 dan p-value 0,045). Satu klaster sekunder yang signifikan di kota Semarang (radius 11511,37 m, dimulai 23 - 29 Juni 2013, jumlah kasus 6 orang, nilai expected 1,78 dan p-value 0,077). 
Tabel 1. Klaster infeksi bersama double DEN serotipe virus dengue di wilayah kajian RT-PCR BBTKLPP Yogyakarta Tahun 20132015

\begin{tabular}{|c|c|c|c|c|c|c|c|}
\hline Wilayah & Serotipe & Radius (m) & Mulai & Berakhir & Observed & Expected & p value \\
\hline \multicolumn{8}{|l|}{ Most likely cluster } \\
\hline 1. Semarang & DEN-1 \& 3 & 15258,36 & 2014-03-25 & 2014-04-16 & 10 & 2,70 & 0,005 \\
\hline 2. Sragen & DEN-1 \& 3 & 11381,42 & 2015-06-14 & $2015-07-22$ & 6 & 0,97 & 0,011 \\
\hline 3.Kota Semarang & DEN-1 \& 3 & 10893,89 & $2013-06-21$ & 2013-06-25 & 5 & 0,68 & 0,024 \\
\hline \multicolumn{8}{|l|}{ Secondary cluster } \\
\hline $\begin{array}{l}\text { 1.G Kidul dan } \\
\text { Bantul }\end{array}$ & DEN-1 \& 2 & 16777,27 & 2014-04-12 & 2014-04-27 & 2 & 0,44 & 0,731 \\
\hline 2.Sleman & DEN-1 \& 2 & 731,22 & 2014-05-30 & 2014-06-07 & 2 & 0,44 & 0,731 \\
\hline 3. Kebumen & DEN-1 \& 2 & 24724,57 & 2014-07-11 & 2014-11-03 & 2 & 0,67 & 0,995 \\
\hline 4. Sleman & DEN-1 \& 2 & 2825,82 & 2014-06-09 & 2014-07-19 & 2 & 0,67 & 0,995 \\
\hline \multicolumn{8}{|l|}{ Secondary cluster } \\
\hline $\begin{array}{l}\text { 1.G Kidul, Sleman } \\
\text { dan Yogyakarta }\end{array}$ & DEN-1 \& 3 & 47723,08 & 2014-04-21 & 2014-07-18 & 6 & 1,14 & 0,052 \\
\hline $\begin{array}{l}\text { 2.Kulon Progo dan } \\
\text { Bantul }\end{array}$ & DEN-1 \& 3 & 14858,54 & 2015-03-06 & $2015-03-20$ & 4 & 0,65 & 0,066 \\
\hline \multicolumn{8}{|l|}{ Secondary cluster } \\
\hline 1.Kebumen & DEN-2 \& 3 & 83838,35 & 2014-05-31 & $2014-10-14$ & 2 & 0,31 & 0,186 \\
\hline 2.Kota Semarang & DEN-2 \& 3 & 2477,69 & 2013-06-07 & 2013-06-22 & 3 & 0,92 & 0,814 \\
\hline Wilayah & Serotipe & Radius (m) & Mulai & Berakhir & Observed & Expected & p value \\
\hline \multicolumn{8}{|l|}{ Most likely cluster } \\
\hline $\begin{array}{l}\text { 1.Seragen dan } \\
\text { kab.Semarang }\end{array}$ & DEN-1, 2 \& 3 & 50332.35 & $2015 / 4 / 1$ & $2015 / 4 / 23$ & 9 & 2.70 & 0,045 \\
\hline \multicolumn{8}{|l|}{ Secondary cluster } \\
\hline 1.Kota Semarang & DEN-1, 2 \&3 & 11511,37 & $2013 / 6 / 23$ & $2013 / 6 / 29$ & 6 & 1,78 & 0,077 \\
\hline 2.Kota Semarang & DEN-1, 2 \&3 & 415.81 & $2013 / 6 / 7$ & $2013 / 6 / 29$ & 2 & 0,15 & 0,298 \\
\hline 3.Kota Semarang & DEN-1, 2 \&3 & 3830.68 & $2013 / 6 / 21$ & $2013 / 6 / 22$ & 4 & 0,89 & 0,443 \\
\hline
\end{tabular}

Peta tematik pola infeksi bersama dan visualisasi buffer model space time permutation disajikan pada Gambar 7 dan 8.

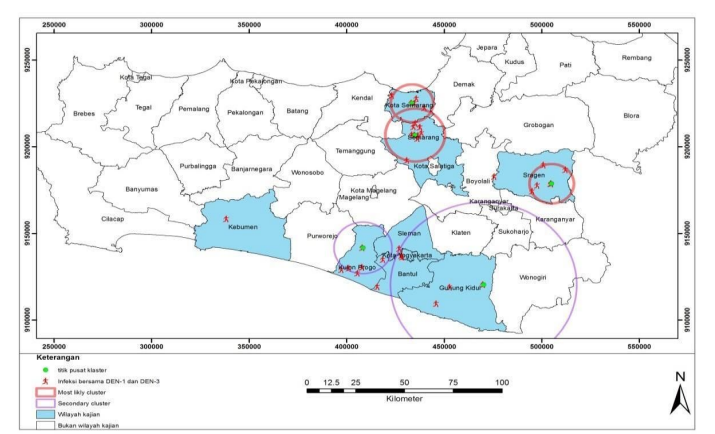

Gambar 7. Buffer klaster infeksi bersama DEN-1 dan DEN-3 pada wilayah kajian RT-PCR BBTKLPP Yogyakarta

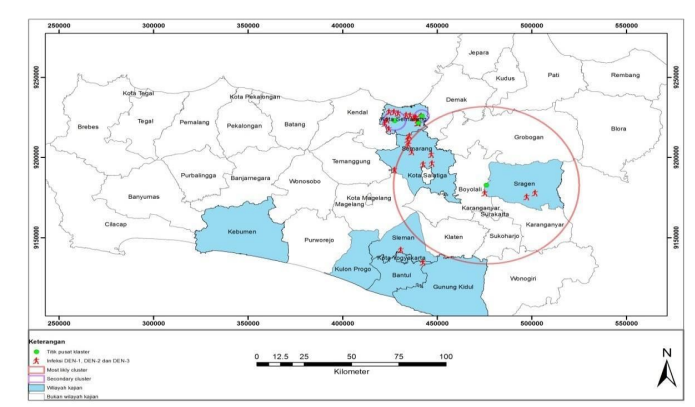

Gambar 8. Buffer klaster infeksi bersama DEN-1, DEN-2 dan DEN-3 pada wilayah kajian RT-PCR BBTKLPP Yogyakarta

\section{BAHASAN}

Distribusi tingkat infeksi bersama serotipe virus dengue. Hasil penelitian menemukan kemiripan tingkat infeksi bersama antara wilayah kajian di DI Yogyakarta dan Jawa Tengah. Identifikasi sampel quadruple DEN melalui kajian RT-PCR di Kota Yogyakarta dan kota Semarang dan mayoritas double DEN pada wilayah Kabupaten Kebumen serta single dan double DEN pada Kabupaten Kulon Progo dapat memberikan gambaran bahwa infeksi bersama yang paling kompleks terdapat pada wilayah kota dibandingkan dengan wilayah kabupaten paling pinggiran. Hal ini dimungkinkan karena adanya infeksi virus dengue dengan distribusi dari ke empat tipe DENV yang sejak awal terjadi dan tinggi pada daerah perkotaan dengan sifat DENV yang tidak dapat memberikan proteksi silang terhadap tipe virus yang berbeda pada infeksi yang berulang.

Penelitian di Thailand menemukan infeksi virus dengue terjadi di daerah perkotaan seperti Bangkok yang kemudian menyebar ke daerah pinggiran seperti Kamphaeng Phet. Virus dengue dilaporkan telah menjangkiti lebih dari 100 negara, terutama di daerah perkotaan dan pemukiman yang berpenduduk padat(6). 
Sirkulasi empat virus dan tingginya infeksi virus dapat berfungsi sebagai indikator kunci dari kemajuan menuju transmisi hiperendemis dengan kemunculan infeksi serotipe virus dengue yang secara bersamaan, terutama pada wilayah kota dan berpenduduk padat(8). Secara invitro, antibodi terhadap virus dengue mempunyai 4 fungsi biologis yaitu netralisasi virus, sitolisis komplemen, antibody dependent cell-mediated cytotoxity (ADCC) dan antibody dependent enhancement (ADE). Proses terjadi infeksi melalui ADE merupakan mekanisme kemunculan kompleks antigen-antibodi. Dalam teori infeksi sekunder disebutkan antibodi yang terbentuk setelah terinfeksi virus untuk pertama kalinya akan menetralisasi virus yang sama (homolog), tetapi jika mendapat infeksi untuk kedua dengan tipe lain maka antibodi heterolog akan membentuk kompleks dengan virus dengue yang baru namun tidak dapat dinetralisasi bahkan membentuk kompleks yang infeksius (2).

Penelitian yang sama oleh Rubens et al,., di kota Fortaleza juga mengemukakan bahwa 2 penderita teridentifikasi kompleks infeksi bersama quadruple DEN. Di Singapura identifikasi serotipe virus dengue dengan metode PRNT berhasil menemukan 57,1\% dari 49 subjek terindentifikasi quadruple DEN, 14,3\% triple DEN, $4 \%$ double DEN dan 24,5\% dengan single DEN (7).

Hasil penelitian yang berbeda oleh Aryati et al,., mengidentifikasi tingkat infeksi bersama double DEN di Surabaya, tingkat infeksi yang sama double DEN juga ditemukan di Padang (8) dan Jawa Barat (9). Beti et al,., mengemukakan adanya infeksi triple DEN di kota Jakarta. Perbedaan tingkat infeksi serotipe virus dengue dimungkinkan karena adanya perbedaan geografis dan waktu pelaksanaan kajian dengan ketersediaan tes diagnostik cepat dari tahun ke tahun sebagai dukungan terhadap surveilans arbovirosis virus dengue (4). Seperti yang dikemukakan oleh Jane et al, adanya laporan infeksi dari tipe DENV yang tinggi di Amerika Serikat tahun 1990-an karena ketersedian tes diagnostik yang cepat (10).

Pola sebaran infeksi bersama serotipe verus dengue. Tingginya infeksi bersama double DEN (DEN-1 dan DEN-3) serta triple (DEN-1, DEN-2 dan DEN-3) hasil kajian surveilans molekular BBTKLPP Yogyakarta, bertepatan dengan KLB infeksi virus dengue di kota Semarang tahun 2013. Infeksi bersama dengan tipe tersebut juga ditemukan pada beberapa wilayah kajian lain di DI Yogyakarta dan Jawa Tengah tahun 2014 dan 2015.

Tiga most likely cluster dari pola infeksi bersama double DEN (DEN-1 dan DEN-3) pada wilayah Jawa
Tengah yaitu kota Semarang, kabupaten Semarang dan Sragen, menunjukkan adanya suatu rantai penularan bersama dari serotipe DEN-1 dan DEN-3 yang bermakna di setiap tahun kajian. Permasalahan ini tentunya menimbulkan kecurigaan apakah penderita dalam klaster terinfeksi dua serotipe berbeda dari nyamuk berbeda atau adanya infeksi lebih dari satu serotipe (DEN-1 dan DEN-3) pada Ae. aegypti atau Ae. albopictus sebagai vektor utama yang kemudian menggigit manusia.

Kemungkinan manusia terinfeksi dengue dapat melalui beberapa gigitan dari nyamuk vektor yang membawa satu atau beberapa virus berbeda (11). Prevalensi infeksi bersama juga mengemukakan bahwa mungkin saja nyamuk yang terinfeksi dua serotipe yang berbeda dapat mengirimkan kedua tipe di daerah di mana dua atau lebih serotipe virus berada (12). Tingkat serangan yang tinggi dari kasus yang terjadi selama epidemi kemungkinan akan mengakibatkan banyak infeksi dengan beberapa serotipe virus pada manusia dan juga memberikan kesempatan bagi nyamuk untuk menjadi terinfeksi dengan dua atau lebih serotipe (13). Spesies nyamuk hadir dalam jumlah besar, menunjukkan bahwa virus telah berubah dari epidemi strain yang beredar di alam secara diam-diam, menyebabkan penyakit yang ringan atau tanpa gejala. Pengamatan serupa telah ditunjukkan dengan virus DEN-3 dan DEN-1 (14).

Gambaran lingkup klaster dengan radius yang cukup jauh pada hasil analisis space time permutation menunjukkan adanya hubungan antara kasus yang dekat dengan yang jauh. Kemampuan analisis permutasi ruang dan waktu adalah membutuhkan asumsi apakah kasus dekat lebih mungkin terkait dengan kasus yang jauh. Pola ini jelas terlihat bahwa adanya aktivitas bepergian manusia sebagai host dalam membantu Ae. aegypti dan Ae. albopictus pada transmisi DENV. Analisis dinamika spasial dan temporal transmisi DENV, terkait dengan adanya penyebaran vektor terinfeksi dan host. Ae. aegypti yang terinfeksi tidak menyebar jauh dari lokasi pemukiman, sehingga manusia bertanggung jawab terhadap transmisi DENV jarak jauh (15).

Interval serial antara penyakit infeksi virus dengue berturut sepanjang rantai penularan setidaknya selama jumlah dari periode inkubasi instrinsik dan ektrinsik. Masa inkubasi intrinsik diduga berkisar dari 2 sampai 12 hari dan paling sering antara 4 dan 6 hari. Periode menular di host bervariasi dari 1 sampai 7 hari atau lebih dan viremia yang paling sering terdeteksi untuk jangka waktu 3 sampai 5 hari. Masa inkubasi ekstrinsik 
bervariasi dengan suhu kamar dan bisa sesingkat 8 atau 20 hari (14).

Hasil penelitian ini menemukan adanya rantai penularan infeksi bersama DEN-1 dan DEN-3 dengan durasi yang beragam. Interval most likely cluster terkuat 23 hari, 37 hari dan 3 hari. Studi kasus infeksi DENV di Puerto Rico, menemukan adanya interval berantai transmisi DENV 17-18 hari. Diperkirakan bahwa interval serial infeksi antara infeksi berturut -turut adalah penting untuk memahami dinamika transmisi DENV (15). Spasial terkuat transmisi DENV terjadi pada interval 15-17 hari, yang menunjukkan interval berantai paling sering antara infeksi DENV manusia berturut-turut. Selain itu dikemukakan juga bahwa kelebihan risiko tinggi pada interval 32-34 hari menunjukkan dua siklus transmisi lengkap dapat diselesaikan dalam area kecil (14). Dalam siklus transmisi DENV, harus dicatat bahwa durasi masa inkubasi ekstrinsik relatif lama untuk taksiran masa harapan hidup Ae. aegypti (15).

Virus dengue masuk ke dalam tubuh manusia lewat gigitan nyamuk Ae. aegypti dan Ae. albopictus selain adanya penularan transeksual dari nyamuk jantan ke nyamuk betina melalui perkawinan serta penularan transovarial dari induk nyamuk ke keturunannya. Penularan yang paling tinggi melalui gigitan nyamuk Ae. aegypti. Adanya distribusi keempat virus, tingginya jumlah penderita, kepadatan penduduk dan urbanisasi serta peningkatan kepadatan vektor dapat mempermudah transmisi virus dengue (2).

Transovarial nyamuk yang terinfeksi mampu menularkan virus melalui gigitan (16). Terdapat pemeliharaan transovarial virus dengue pada daerah endemik. Penularan vertikal mungkin salah satu faktor yang menyediakan mekanisme bagi virus untuk bertahan di musim kemarau dan musim dingin dengan populasi nyamuk rendah. Jakrawarn et al, dalam penelitiannya di empat pusat provinsi di Thailand menemukan keempat serotipe dengue di larva Ae. Aegypti dan orang dewasa dengan DENV-3 dan DENV-1 adalah dua serotipe yang paling umum. Serotipe virus dengue dalam spesimen darah pasien diduga menunjukkan hasil yang sama seperti yang diperoleh di nyamuk yaitu DENV-1 dan DENV-3 yang merupakan dua tipe paling dominan. Terdapat laporan beberapa infeksi dengan serotipe DENV yang berbeda mungkin di daerah hiperendemisitas (16).

Identifikasi epidemi infeksi bersama pada beberapa wilayah berbeda diharapkan menjadi gambaran, bukti transmisi dari infeksi bersama DEN-1 dan DEN-3. Pada studi outbreak di Indo-Myanmar selama Oktober 2007 di kota More menemukan 27,5\% dari 40 teridentifikasi infeksi bersama DEN-1 dan DEN-3, ini merupakan tipe yang paling tinggi dibandingkan DEN-2 dan DEN-3 serta DEN-1 dan DEN-4 yang hanya ditemukan 1 kasus. Sebelumnya di Delhi India tahun 2006 juga ditemukan 44,9\% transmisi bersama DEN-1 dan DEN-3 (17).

Di Indonesia tahun 1976-1978 khususnya DI Yogyakarta dan Jakarta, 27,5\% teridentifikasi infeksi bersama DEN-1 dan DEN-3 dari 11 sampel positif, demikian di Marida/ Meksiko tahun 1996, juga ditemukan infeksi yang sama dari DEN-1 dan DEN-3 (13). Studi di Surabaya menemukan infeksi bersama yang tinggi dari DEN-1 dan DEN-3 pada 7 penderita (9,86\%) (3). Tahun 2014 di Padang ditemukan infeksi bersama DEN-1 dan DEN-3 pada anak, dengan NS1 positif pada tahap awal (8).

Dominasi double virus yang menginfeksi adalah DEN-1 dan DEN-2 dan DEN-2 dan DEN-3 (18). Deteksi infeksi campuran DEN-1 dan DEN-3 di Srilanka bertepatan dengan puncak wabah pada pertengahan 2009 (19)I,dalam penelitian terkait epidemi dengue di Peru juga menemukan infeksi bersama didominasi DEN-1 dan DEN-3 (8,2\% dari 73). Selama tahun 2004 di Thailand dari laporan medis ditemukan adanya infeksi bersama DEN-1 dan DEN-3 pada penderita anak (20) .

Pola infeksi bersama dari tiga serotipe yang berbeda yaitu DEN-1, DEN-2 dan DEN-3 dengan pola yang cukup luas yang melibatkan kawasan berbeda. Satu most likely cluster dengan durasi 22 hari mencakup wilayah kabupaten Sragen dan kabupaten Semarang dan 1 klaster sekunder yang signifikan durasi 3 hari, di kota Semarang. Karakteristik waktu antara infeksi berturut -turut dalam rantai penularan akan membantu untuk lebih memahami dinamika transmisi kawasann (15).

Infeksi bersama DEN-1, 2 dan DEN-3 selain infeksi bersama DEN-1 dan DEN-3 (20). Dominasi serotipe DEN-1, DEN-2 dan DEN-3 bertanggung jawab terhadap kejadian demam berdarah dengue di Singapura sejak tahun 1986 (21). Pada outbreak di India tahun 2010 selain ditemukan infeksi bersama dua tipe yaitu DEN-2 dan DEN-3 serta DEN-1 dan DEN-2, satu-satunya kombinasi triple DEN yaitu DEN-1, 2 dan 3 ikut berperan dalam kejadian tersebut (22). Penelitian lain menemukan hasil berbeda. Wabah dengue yang terjadi di Pakistan terkait dengan peran DEN-2,3 dan DEN-4.

Data isolasi DENV (serotipe virus dengue) merupakan data sekunder yang diperoleh dari hasil kajian RT-PCR BBTKLPP tahun 2013-2015. Pemetaan jarak jauh dilakukan dengan penentuan titik koordinat kasus berdasarkan desa alamat responden yang tersedia pada data surveilans arbovirosis dengue BBTKLP Yogyakarta dengan pemanfaatan google Earth, Argis on line dan 
peta RBI. Penelitian ini hanya melihat distribusi DENV yang teridentifikasi pada penderita, tidak melihat DENV pada nyamuk Ae. aegyti dan albopictus sebagai vektor utama dalam penyebaran infeksi DENV.

\section{SIMPULAN}

Wilayah dengan tingkat infeksi bersama yang paling kompleks adalah kota Semarang dan kota Yogyakarta. Terdapat 3 pola most likely cluster infeksi bersama DEN-1 dan DEN-3 meliputi: kabupaten Semarang tahun 2014, Sragen tahun 2015 dan kota Semarang tahun 2013 serta 2 secondary cluster signifikan di kabupaten Gunung Kidul tahun 2014 dan Kulon Progo tahun 2015. Satu pola most likely cluster dari infeksi bersama DEN-1, DEN-2 dan DEN-3 tahun 2015 yang mencakup kabupaten Sragen dan Semarang serta 1 secondary cluster di kota Semarang tahun 2013.

Pasien yang terinfeksi virus dengue dari wilayah kota Semarang dan kota Yogyakarta sebaiknya saat ditemukan langsung dirawat. Bagi BBTKLPP Yogyakarta maupun peneliti lain, untuk dapat melakukan kajian lebih lanjut terhadap kemungkinan indikasi infeksi bersama serotipe virus dengue pada Ae. aegypti dan Ae. albopictus di wilayah klaster utama infeksi bersama serotipe virus dengue yang ditemukan.

\footnotetext{
Abstrak

Tujuan: Kajian ini bertujuan untuk mengetahui pola sebaran tingkat infeksi bersama serotipe virus dengue di wilayah kajian RT-PCR BBTKLPP Yogyakarta tahun 2013-2015 Metode: Penelitian ini bersifat deskriptif dengan metode spasial. Pengumpulan data 132 responden bersumber pada hasil RT-PCR BBTKLPP Yogyakarta tahun 2013-2015. Alamat lengkap penderita level desa dari data surveilans arbovirosis dengue BBTKLPP Yogyakarta digunakan untuk menggambarkan titik koordinat dengan pemanfatan peta RBI dan google Earth dalam mencari alamat/desa serta penentuan sebaran titik koordinat kasus. Analisis ini dilakukan untuk melihat tingkat dan pola infeksi berdasarkan wilayah kajian BBTKLPP Yogyakarta. Hasil: Terdapat kemiripan tingkat infeksi bersama yang paling kompleks quadruple DEN pada kota Semarang dan kota Yogyakarta, Pada kabupaten Kebumen didapatkan tingkat double DEN. Tiga pola infeksi bersama DEN-1 dan DEN-3 dengan p-value < 0,05 di kabupaten Semarang tahun 2014, Sragen tahun 2015 dan kota Semarang tahun 2013 serta 2 pola $p$-value <
}

0,1 di Gunung Kidul tahun 2014 dan Kulon Progo tahun 2015. Pola infeksi bersama DEN-1, DEN-2 dan DEN-3 tahun 2015 dengan $p$-value $<0,05$ mencakup kabu- paten Sragen dan Semarang serta pola $p$-value < 0,1 di kota Semarang tahun 2013. Simpulan: Wilayah tingkat infeksi bersama paling kompleks adalah kota Semarang dan kota Yogyakarta. Pola most likely cluster infeksi bersama DEN-1 dan DEN-3 serta DEN-1, DEN-2 dan DEN-3, diduga akibat penderita terinfeksi dua serotipe berbeda dari nyamuk berbeda atau adanya infeksi lebih dari satu serotipe pada Ae. aegypti atau Ae. albopictus sebagai vektor utama. Perlu penelitian lebih lanjut untuk dapat membukti- kan adanya infeksi oleh beberapa serotipe berbeda pada Ae. aegypti atau Ae. albopictus sebagai vektor utama.

Kata kunci: wilayah; tingkat infeksi bersama; serotipe; virus dengue

\section{PUSTAKA}

1. WHO. Impact of Dengue. Available from: http:// www.who.int. Accessed 28 December 2015.

2. Soegijanto. Demam Berdarah Dengue, Edisi dua, Airlangga University, Surabaya; 2006.

3. Aryati, Wardhani, Yohan, Aksono dan Tedjo Sasmono. Distribusi Serotipe Dengue di Surabaya Tahun 2012. Indonesia Journal of Clinical Pathology and Medical Laboratory, Vol.19. 1, November 2012: 41-44. Diakses tanggal 4 Januari 2016

4. Beti, Naiggolan, Putri, Rachmayanti, Albar, Indriastuti, Sjamsuridzal and Mirawati. Characterization of Dengue Virus Serotype 4 Infection in Jakarta, Indonesia, 2014;45(1) January 2014.

5. Rafiq, Arif and Shaikh. Dengue In Pakistan: Journey From a Disease Free to a Hyper Endemic Nation Editorial. University of Health Sciences Karachi, 2011;5(3): 81-84.

6. Wardani DW, Lazuardi L, Mahendradhata Y, Kusnanto H. Pentingnya Analisis Cluster Berbasis Spasial dalam Penanggulangan Tuberkulosis di Indonesia. Kesmas: National Public Health Journal. 2013 Nov 1:147-51.

7. Lima JR, Rouquayrol MZ, Callado MR, Guedes MI, Pessoa C. Interpretation of the presence of IgM and IgG antibodies in a rapid test for dengue: analysis of dengue antibody prevalence in Fortaleza City in the 20th year of the epidemic. Revista da Sociedade Brasileira de Medicina Tropical. 2012 Apr;45(2):163-7.

8. Megariani M, Mariko R, Alkamar A, Putra AE. Uji diagnostik pemeriksaan antigen nonstruktural 1 untuk deteksi dini infeksi virus dengue pada anak. Sari Pediatri. 2016 Nov 9;16(2):121-7.

9. Prasetyowati P, Nusa R. DHF cases dominated by Den-3 serotype in the West Java province. Health Science Journal of Indonesia. 2012;3(1 Jun):23-6. 
10. Messina JP, Brady OJ, Scott TW, Zou C, Pigott DM, Duda KA, Bhatt S, Katzelnick L, Howes RE, Battle $\mathrm{KE}$, Simmons CP. Global spread of dengue virus types: mapping the 70 year history. Trends in microbiology. 2014 Mar 1;22(3):138-46.

11. Thavara U, Siriyasatien P, Tawatsin A, Asavadachanukorn P, Anantapreecha S, Wongwanich R, Mulla MS. Double infection of heteroserotypes of dengue viruses in field populations of Aedes aegypti and Aedes albopictus (Diptera: Culicidae) and serological features of dengue viruses found in patients in southern Thailand.

12. Araújo FM, Nogueira RM, Araújo JM, Ramalho IL, Roriz ML, Melo ME, Coelho IC. Concurrent infection with dengue virus type-2 and DENV-3 in a patient from Ceará, Brazil. Memórias do Instituto Oswaldo Cruz. 2006 Dec;101(8):925-8.

13. PLorono-Pino MA, Cropp CB, Farfan JA, Vorndam $\mathrm{AV}$, Rodriguez-Angulo EM, Rosado-Paredes EP, Flores-Flores LF, Beaty BJ, Gubler DJ. Common occurrence of concurrent infections by multiple dengue virus serotypes. The American journal of tropical medicine and hygiene. 1999 Nov 1;61(5):725-30.

14. Gubler DJ. Dengue and dengue hemorrhagic fever. Clinical microbiology reviews. 1998 Jul 1;11(3):480-96.

15. Aldstadt J, Yoon IK, Tannitisupawong D, Jarman RG, Thomas SJ, Gibbons RV, Uppapong A, Iamsirithaworn S, Rothman AL, Scott TW, Endy T. Space-time analysis of hospitalised dengue patients in rural Thailand reveals important temporal intervals in the pattern of dengue virus transmission. Tropical medicine \& international health. 2012 Sep 1;17(9):1076-85.
16. Chompoosri J, Thavara U, Tawatsin A Anantapreecha S, Siriyasatien P. Seasonal monitoring of dengue infection in Aedes aegypti and serological feature of patients with suspected dengue in 4 central provinces of Thailand. The Thai Journal of Veterinary Medicine. 2012 Jul 1;42(2):185.

17. Bharaj P, Chahar HS, Pandey A, Diddi K, Dar L, Guleria R, Kabra SK, Broor S. Concurrent infections by all four dengue virus serotypes during an outbreak of dengue in 2006 in Delhi, India. Virology Journal. 2008 Dec;5(1):1.

18. Khan J, Khan A. Incidence of dengue in 2013: dengue outbreak in District Swat, Khyber Pakhtunkhwa, Pakistan. Inter J of Fauna and Biolo Stud. 2015;2(1):1-7.

19. Dissanayake VH, Gunawardena ND, Gunasekara NC, Siriwardhana DR, Senarath N. Shift in the transmission pattern of dengue serotypes and concurrent infection with more than one dengue virus serotype. Ceylon Medical Journal. 2011 Dec 30;56(4)

20. Zhang C, Mammen MP, Chinnawirotpisan $P$, Klungthong C, Rodpradit P, Monkongdee P, Nimmannitya S, Kalayanarooj S, Holmes EC. Clade replacements in dengue virus serotypes 1 and 3 are associated with changing serotype prevalence. Journal of virology. 2005 Dec 15;79(24):15123-30.

21. Wilder-Smith A, Yoksan S, Earnest A, Subramaniam R, Paton NI. Serological evidence for the co-circulation of multiple dengue virus serotypes in Singapore. Epidemiology \& Infection. 2005 Aug;133(4):667-71.

22. Anoop M, Issac A, Mathew T, Philip S, Kareem NA, Unnikrishnan R, Sreekumar E. Genetic characterization of dengue virus serotypes causing concurrent infection in an outbreak in Ernakulam, Kerala, South India. 